\title{
A GIS-Based Framework for Real-Time Debris-Flow Hazard Assessment for Expressways in Korea
}

\author{
Han-Saem Kim ${ }^{1}$ - Choong-Ki Chung ${ }^{2}$ Sang-Rae Kim ${ }^{3} \cdot K_{\text {Kung-Suk Kim }}^{4}$
}

Published online: 21 September 2016

(c) The Author(s) 2016. This article is published with open access at Springerlink.com

\begin{abstract}
Debris flows caused by heavy rainfall in mountain areas near expressways lead to severe social and economic losses and sometimes result in casualties. Therefore, the development of a real-time system for debris-flow hazard assessment is necessary to provide preliminary information for rapid decision making about evacuations or restoration measures, as well as to prevent secondary disasters caused by debris flows. Recently, various map-based approaches have been proposed using multi-attribute criteria and assessment methods for debrisflow susceptibilities. For the macrozonation of debris-flow hazard at a national scale, a simplified method such as the Korea Expressway Corporation (KEC) debris-flow hazard assessment method can be applied for systematic analysis based on geographic information systems (GIS) and monitoring networks. In this study, a GIS-based framework of real-time debris-flow hazard assessment for expressway sections is proposed based on the KEC debris-flow hazard assessment method. First, the KEC-based method was standardized in a systematic fashion using ArcGIS, enabling the objective and quantitative acquisition of
\end{abstract}

Choong-Ki Chung

geolabs@snu.ac.kr

1 Earthquake Research Center, Korea Institute of Geoscience and Mineral Resources, 124 Gwahak-ro, Daejeon, Korea

2 Department of Civil and Environmental Engineering, Seoul National University, 1 Gwanak-ro, Seoul, Korea

3 Department of Civil and Environmental Engineering, Northwestern University, 633 Clark St, Evanston, USA

4 Expressway and Transportation Research Institute, Korea Expressway Corporation, 922 Dongbu-daero, Hwaseong, Korea various attribute datasets. The quantification of rainfall criteria also was considered. A safety management system for debris-flow hazard was developed based on the GIS platform. Finally, the method was applied and verified on three expressway sections in Korea. The grading standard for each individual influencing attribute was subsequently modified to more accurately assess the debris-flow hazards.

Keywords Debris-flow hazard · Expressway management · GIS · Korea · Real-time hazard assessment

\section{Introduction}

Landslides, and in particular debris flows, are one of the most damaging natural hazards in mountainous terrain that experiences heavy torrential rainfall. Rainfall-triggered landslides are a recurring problem in Korea due to a combination of mountainous terrain, a shallow layer of alluvial soil, and associated weather conditions (Hungr et al. 2001; Park et al. 2013). "Flowage" or "flow" is the term used to describe the downslope movement of unconsolidated material in which particles move about and mix within the mass, such as earthflows, debris flows, or avalanches. To avoid confusion resulting from the interchangeable use of terminology, the term "debris flow" in this study refers to the fluid mixture of rocks, sand, mud, and water that is intermediate between a landslide and a water flood (Feusto et al. 1999; Keller and DeVecchio 2008).

Debris-flow damage includes loss of human life, destruction of facilities, and damage to roads, pipelines, and vehicles (Jakob and Hungr 2005). Until now, only post-event repairs and protective infrastructure improvements have generally been executed after debris-flow 
occurrences. Recently, an increase has occurred in Korea in both the number of occurrences of and the costs for countermeasures against debris flows. In order to sufficiently manage and protect expressway sections and facilities that are exposed to debris-flow occurrences, a method to assess the hazard of debris flows during certain rainfall events at a regional scale is needed. Infiltration of prolonged, intense rainfall, which causes soil saturation and a temporary increase in pore water pressure, is the mechanism by which most shallow landslides, and more specifically debris flows, are generated during rainstorms (Iverson 2000; Keller and DeVecchio 2008). Because Korea is a region with heavy, concentrated, torrential rainfall in the summer, most of the debris flows occur during the rainy summer periods in mountainous regions. Due to climate change and other environmental factors, the intensity and frequency of rainfall events are increasing. This increase results in a greater number of debris-flow occurrences and higher restoration costs than in the past. Consequently, more debris-flow countermeasures are now necessary for the safety and preservation of human lives and infrastructure.

Assessment of landslides, including debris flows, has been carried out with geographic information systems (GIS) techniques combined with statistical analyses and physical-based approaches by various researchers such as Carrara et al. (1999), Dai and Lee (2002), Ohlmacher and Davis (2003), Ayalew et al. (2004), Wang et al. (2008), and Kritikos and Davies (2015). In spite of the importance of GIS approaches, there are few techniques for debris-flow zonation and geodatabase analysis, and there is no practical and standardized debris-flow mapping method using GIS (Paulín et al. 2014). Through comparison and review of existing studies on the factors that influence debris flow and appropriate assessment methods, the Korea Expressway Corporation (KEC) debris-flow hazard assessment method was developed as a fundamental assessment tool (Korea Expressway Corporation 2009). This eclectic method focuses on the probable occurrence of road structure hazards in a highway system. The method can be quantitatively and objectively performed in a simple manner by using documents such as numerical maps and expressway design files. By drawing on existing databases, the method minimizes the need for tiresome field investigations in countless potential debris-flow occurrence regions in vast areas. Above all, in order to immediately assess rainfall-induced debris flows, rainfall criteria were utilized to determine fundamental trigger values and indices for the severity level of debris flows.

According to the KEC method, zonation of debris-flow hazard is evaluated through two indices: susceptibility value and vulnerability value. The susceptibility value indicates the likelihood of debris-flow occurrence, and can be estimated with the topography information available on target locations. The vulnerability value is used to represent whether an occurred debris flow will damage or have an impact on specific expressway sections, and can be assessed from the capacity of the drainage facility and the roadside margin area for sedimentation of debris-flow materials before they reach expressway structures. Determination of these influencing factors is achieved through the use of digital maps and expressway design files. The calculated susceptibility value and vulnerability value are used to indicate a single hazard class (Fig. 1), which represents the likelihood of damage by debris-flow events under a given rainfall intensity.

In this study, the GIS-based framework of real-time debris-flow hazard assessment for expressway sections was proposed based on the KEC debris-flow hazard assessment method. To standardize the KEC method, a systematic sequence for the acquisition of attribute values was proposed using Arcgis 10.2 (Esri 2006). Then to consider the real-time link with the Automatic Weather Station (AWS) network in the Korean Meteorological Administration, ${ }^{1}$ the rainfall recurrence periods were quantified as accumulated rainfall using the trigger values of past debris-flow occurrence events. Following the optimization of the KEC debris-flow hazard assessment method, a safety management system for debris-flow hazards was developed based on the ArcGIS platform. This system consists of a database (DB) and four systematic submodules: the input module, the debris-flow hazard assessment module, decision-making module of debris-flow countermeasure, and the real-time prediction module of debris-flow hazard, which is linked to the rainfall monitoring network. Finally, an applicability evaluation of the framework was carried out on three expressway sections of the Korean highway system that have suffered damage due to debris-flow occurrences during heavy rainfall events in 2005 and 2006: the Pyeongchang area of the Yeongdong Expressway, the Deogyu Mountain area of the Daejun-Jinju Expressway, and the Juksan-Geochang area of the 88 Expressway. The reliability of the assessment method was investigated by comparing the actual debris-flow occurrence and nonoccurrence cases.

\section{Literature Review of Debris-Flow Hazard Assessment}

A review of methods for debris-flow hazard assessment, including those by Dai and Lee (2002), Lin et al. (2002), Ayalew et al. (2004), Lee and Pradhan (2007), Blahut et al. (2010), Yune et al. (2010), and Lee et al. (2012), permits a comparative analysis of the influential attributes and hazard

\footnotetext{
$\overline{1}$ www.kma.go.kr/weather/observation/aws_table_popup.jsp.
} 


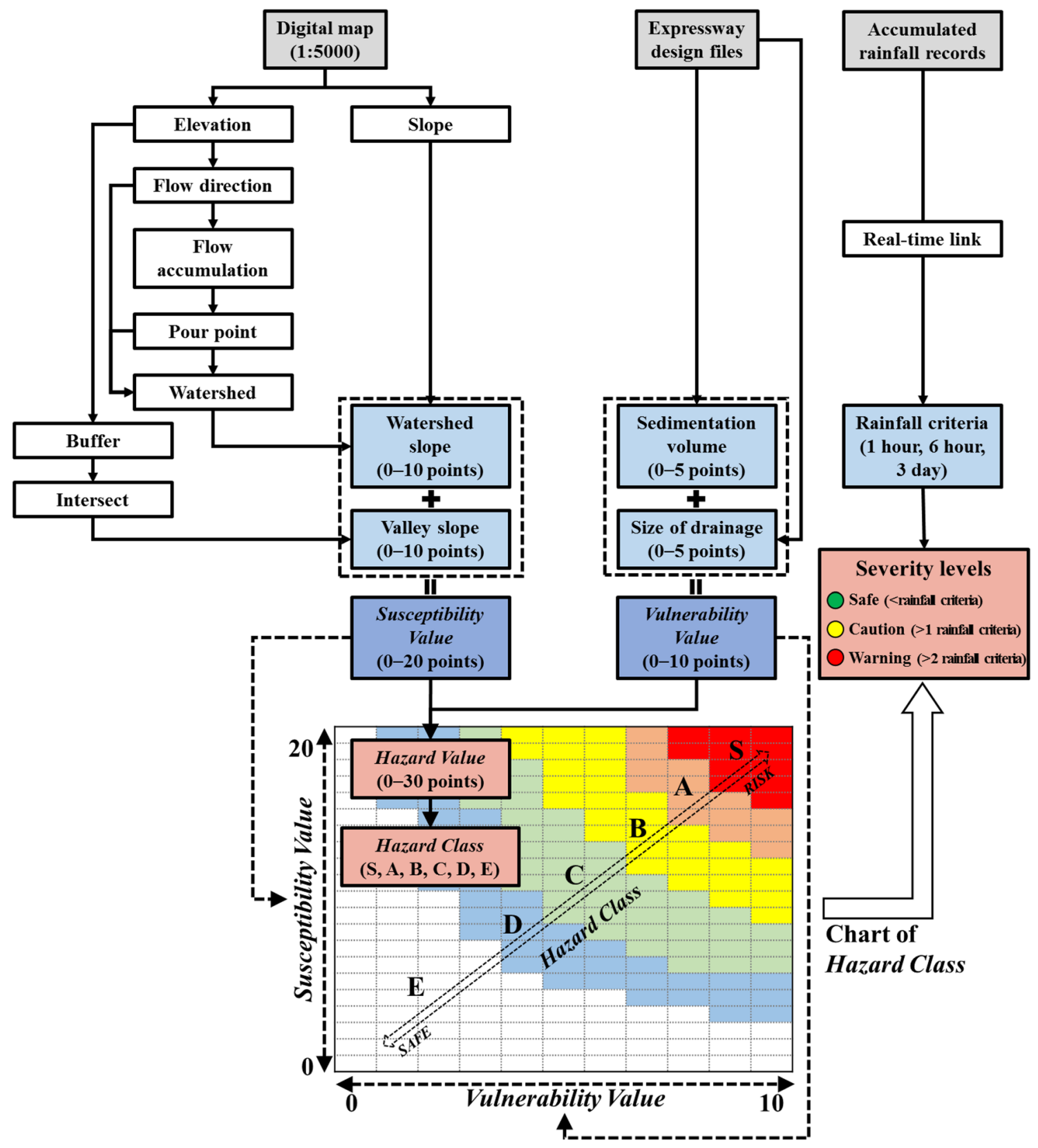

Fig. 1 Real-time debris-flow hazard assessment framework for expressways

assessment methods of debris flows. Debris-flow hazards are dependent on a specific set of factors and processes that are usually investigated by various experts (such as hydrologists, geologists, or civil engineers). Prediction concerns where and/or when debris flow will occur, and depends on the type of movement and the scope of the forecasting. Many attributes (geography, rainfall, geology, vegetation, wildfire history, and conditions of existing structures) are related to the mechanism/initiation of debris flows (Table 1).

To obtain information on the influencing factors other than topographical properties (elevation, slope, valley shape, and watershed size) and rainfall data, field surveys should be thoroughly conducted throughout entire expressway facility sections. Because the assessment of debris-flow hazards in this study is to be applied on a regional scale for management of the entire national expressway system, the method needs to be simple and applicable to the macrozonation of debris-flow hazards. Other factors, such as the size and shape of a valley along with the variations in slope direction, properties of the subsoil, geological properties, and vegetation cover also have an influence on the movement of debris flows. To simplify the method, only slope information was 
Table 1 Debris-flow influencing factors and existing survey methods

\begin{tabular}{|c|c|c|}
\hline Influencing factor & Influencing attribute & Survey method \\
\hline \multirow[t]{5}{*}{ Topographical property } & Elevation & Digital map \\
\hline & Slope (angle, direction, and shape) & DEM (digital elevation model) \\
\hline & Valley (length, slope, and width) & Remote sensing \\
\hline & Watershed (area and slope) & Satellite image \\
\hline & Initial zone (area, volume, shape, and failure type) & Field survey \\
\hline Hydrological property & Rainfall (Max., intensity, recurrence period, and accumulated rainfall) & AWS (automatic weather station) \\
\hline \multirow[t]{9}{*}{ Geological property } & Lithology & Geological map \\
\hline & Bedding plane angle & \\
\hline & Moisture content & Field survey \\
\hline & Void ratio & \\
\hline & Porosity & \\
\hline & Saturation & \\
\hline & Density & \\
\hline & Permeability & \\
\hline & Groundwater & \\
\hline \multirow[t]{2}{*}{ Vegetation property } & Tree (species and tensile strength of the root) & Stock map \\
\hline & Wildfire history & Field survey \\
\hline \multirow[t]{3}{*}{ Structural fragility } & Sedimentation volume & Design file \\
\hline & Size of drainage & \\
\hline & Fragility curve & \\
\hline
\end{tabular}

considered for debris-flow movement possibilities. Because obtaining and processing all the attributes stated above in the prediction stage is a time-consuming and difficult task, we decided that only easily accessible document data (such as digital maps, geological maps, and so on) were to be used in the assessment process. For example, the spatial correlations (for site-specific microscale areas) between influence of debris flow and geological or vegetation characteristics were not well investigated in Korea. Since most debris flows regardless of scale are induced by regional torrential rains, available and reliable influencing attribute data such as rainfall and digital map is necessary to immediately evaluate the debris-flow hazard for a wide coverage area. Consequently, the KEC debris-flow hazard assessment method has become a fundamental assessment tool owing to its simplicity.

As a precautionary measure, the KEC method assesses the hazard of debris flows at a regional scale using a limited number of datasets. Only digital elevation models (DEMs) and expressway design files of the target area were used. The DEMs that were used in the assessment process were those provided by the National Geographic Information Institute (NGII) of Korea, whereas the expressway design files were provided by the Korea Expressway Corporation. Through the application and use of only easily accessible datasets, the KEC hazard assessment method minimizes the need for time-consuming field investigation, and allows rapid hazard assessment of debris flows in large area (administrative sections or nationwide). Accordingly, the DEM for elevation and slope was used to evaluate the watershed information containing topographical route condition of rainfall-induced debris flow. Two indices-the susceptibility value and vulnerability value-were used to evaluate debris-flow hazard.

The susceptibility value indicates the likelihood of debris-flow occurrence in a target area and is assessed using a total of four attributes. The mean watershed slope and area percentage of watershed with slopes over $35^{\circ}$ are used to assess debris-flow initiation. Mean valley slope and length percentage of valley with slopes over $15^{\circ}$ are used for the assessment of debris-flow movement. Other factors such as the size and shape of the valley along with variations in slope direction, properties of the subsoil, and vegetation also have an influence on the initiation and movement of debris flows. To simplify the method, only the slope information derived from the DEMs is considered for debris-flow possibilities. Each of the influencing factors are assigned points from 0 to 5 based on the grading standard set (Table 2) considering past debris-flow occurrence cases for 10 years (from 2000 to 2009), when the annual precipitation rate amounted to $3000 \mathrm{~mm}$ and adds up to a maximum total susceptibility value of 20 points. 
Table 2 Points given to attributes according to the grading standard of KEC

\begin{tabular}{|c|c|c|c|c|}
\hline & & & Scoring Index & Points \\
\hline \multirow{24}{*}{$\begin{array}{l}\text { Susceptibility } \\
\text { Value } \\
\text { (20 points) }\end{array}$} & \multirow{12}{*}{$\begin{array}{l}\text { Initiation } \\
\text { assessment } \\
\text { (10 points) }\end{array}$} & \multirow{6}{*}{$\begin{array}{l}\text { Mean slope of } \\
\text { watershed } \\
\left(\text { Unit: }^{\circ}\right)\end{array}$} & Higher than $35^{\circ}$ & 5 \\
\hline & & & $30^{\circ}-35^{\circ}$ & 4 \\
\hline & & & $25^{\circ}-30^{\circ}$ & 3 \\
\hline & & & $20^{\circ}-25^{\circ}$ & 2 \\
\hline & & & $15^{\circ}-20^{\circ}$ & 1 \\
\hline & & & Under $15^{\circ}$ & 0 \\
\hline & & \multirow{6}{*}{$\begin{array}{l}\text { Area } \\
\text { percentage of } \\
\text { watershed with } \\
\text { slopes over } 35^{\circ} \\
(\text { Unit: \%) }\end{array}$} & Higher than $40 \%$ & 5 \\
\hline & & & $30 \%-40 \%$ & 4 \\
\hline & & & $20 \%-30 \%$ & 3 \\
\hline & & & $10 \%-30 \%$ & 2 \\
\hline & & & $1 \%-10 \%$ & 1 \\
\hline & & & Under $1 \%$ & 0 \\
\hline & \multirow{12}{*}{$\begin{array}{l}\text { Movement } \\
\text { assessment } \\
\text { (10 points) }\end{array}$} & \multirow{6}{*}{$\begin{array}{l}\text { Mean valley } \\
\text { slope } \\
\left(\text { Unit: }^{\circ} \text { ) }\right.\end{array}$} & Higher than $25^{\circ}$ & 5 \\
\hline & & & $20^{\circ}-25^{\circ}$ & 4 \\
\hline & & & $15^{\circ}-20^{\circ}$ & 3 \\
\hline & & & $10^{\circ}-15^{\circ}$ & 2 \\
\hline & & & $5^{\circ}-10^{\circ}$ & 1 \\
\hline & & & Under $5^{\circ}$ & 0 \\
\hline & & \multirow{6}{*}{$\begin{array}{l}\text { Length } \\
\text { percentage of } \\
\text { valley with } \\
\text { slopes over } 15^{\circ} \\
\text { (Unit: \%) }\end{array}$} & Higher than $90 \%$ & 5 \\
\hline & & & $70 \%-90 \%$ & 4 \\
\hline & & & $50 \%-70 \%$ & 3 \\
\hline & & & $30 \%-50 \%$ & 2 \\
\hline & & & $10 \%-30 \%$ & 1 \\
\hline & & & Under $10 \%$ & 0 \\
\hline \multirow{12}{*}{$\begin{array}{l}\text { Vulnerability } \\
\text { Value } \\
\text { (10 points) }\end{array}$} & \multirow{6}{*}{$\begin{array}{l}\text { Debris storage } \\
\text { ( } 5 \text { points) }\end{array}$} & \multirow{6}{*}{$\begin{array}{l}\text { Volume of } \\
\text { deposit area } \\
\left(\text { Unit: } \mathrm{m}^{3} \text { ) }\right.\end{array}$} & No accumulation area $\left(0 \mathrm{~m}^{3}\right)$ & 5 \\
\hline & & & $0 \mathrm{~m}^{3}-100 \mathrm{~m}^{3}$ & 4 \\
\hline & & & $100 \mathrm{~m}^{3}-1000 \mathrm{~m}^{3}$ & 3 \\
\hline & & & $1000 \mathrm{~m}^{3}-5000 \mathrm{~m}^{3}$ & 2 \\
\hline & & & Higher than $5000 \mathrm{~m}^{3}$ & 1 \\
\hline & & & $\begin{array}{l}\text { Excessive volume of deposit area, } \\
\text { No damage guaranteed }\end{array}$ & 0 \\
\hline & \multirow{6}{*}{$\begin{array}{l}\text { Debris passage } \\
\text { through } \\
\text { expressway } \\
\text { facilities } \\
\text { ( } 5 \text { points) }\end{array}$} & \multirow{6}{*}{$\begin{array}{l}\text { Size of } \\
\text { drainage } \\
\text { facility } \\
\text { (Unit: m) }\end{array}$} & Waterway & 5 \\
\hline & & & Lateral drains below D1.2 & 4 \\
\hline & & & Waterway box below B1.0x1.0 & 3 \\
\hline & & & Waterway box below B4.0x4.0 & 2 \\
\hline & & & $\begin{array}{l}\text { Waterway box exceeding B4.0x4.0- } \\
\text { Discharge section under } 30 \mathrm{~m}^{2}\end{array}$ & 1 \\
\hline & & & Small bridges & 0 \\
\hline
\end{tabular}

Source Korea Expressway Corporation (2009)

Note $\mathrm{D}$ is the diameter of lateral drains and $\mathrm{B}$ is the width of waterway box for the scoring index of debris passage through expressway facilities. Debris passage through expressway facilities is defined as the designed sedimentation volume of debris flow from valley to waterway under the expressway 
For the weight considerations of the four attributes, logistic regression was carried out through the Statistical Package for Social Science. The occurrence of debris flow is "one" when it happened and "zero" when there was no occurrence. Logistic regression has been used frequently for multivariable analysis (Ohlmacher and Davis 2003; Ayalew and Yamagishi 2005; Lee and Pradhan 2007). In this study logistic regression is used to estimate the correlation between the dependent variable (occurrence of debris flow) and independent variables (influencing attributes) by evaluating probabilities using a logistic function. Results of logistic regression analyses using datasets from 30 debrisflow cases show that the four susceptibility value attributes had weights of $0.27,0.24,0.26$, and 0.23 , respectively. Since the weights showed no significant difference, the attributes were considered to have identical weights.

The vulnerability value indicates whether a debris flow will actually damage or have an impact on expressway sections. The vulnerability value is assessed by two attributes: the volume of margin area available in which to deposit debris-flow materials before reaching expressway structures; and the size of drainage facilities running through the expressway. For the acquisition of the attribute values, expressway design files provided by the Korea Expressway Corporation were used. Each of the attributes is given points ranging from 0 to 5 based on a grading standard (Table 2), and these points are added up to provide the total vulnerability value of 10 points.

By combining the calculated susceptibility value and vulnerability value (Fig. 1), a hazard class is given for a target expressway section. In the table of severity rating shown in the chart of hazard class (Fig. 1), the x-axis and $y$-axis indicate the vulnerability value and susceptibility value, respectively. Through investigations on past debrisflow occurrences, the hazard classes were categorized according to the rainfall recurrence period for expressway design purposes. Hazard class S indicates a likelihood of debris-flow occurrences in areas with rainfall recurrence periods of 2-5 years. Hazard classes A, B, C, and D have rainfall recurrence periods of 5-20, 20-50, 50-100 years, and over 100 years, respectively. Hazard class E indicates an area with a very low likelihood of debris-flow damage (Korea Expressway Corporation 2009).

\section{GIS-Based Framework for Debris-Flow Assessment}

Based on the processing of attributes included in the KEC method, a real-time debris-flow hazard assessment framework for expressways was newly developed using the ArcGIS 10.2 software (Fig. 1). Various ArcGIS tools, such as the Spatial Analyst tools and the Analysis tools, were used for a quantitative and objective assessment of the attributes using rainfall datasets on a real-time basis.

\subsection{Attribute Processing for the Susceptibility Value}

In order to process watershed slope and valley slope datasets, DEMs provided by the NGII of Korea were used. Numerical maps with the highest resolution were those of a scale of 1:1000. But 1:1000 scale numerical maps were only provided for major urban areas. Because numerical maps of the highest resolution provided for the entire Korean Peninsula were those of 1:5000 scale, numerical maps with a scale of 1:5000 were employed in attribute processing to obtain the susceptibility value.

Of the entities within the DEMs, only the polyline and point entities having elevation value were extracted from the numerical map and used for construction of the DEMs. Because the system focuses on the debris-flow hazard assessment of expressway facilities, the expressway layers were selected. For the processing of slopes in the surrounding area of expressways, the elevation layers were also selected (Fig. 2a). With the elevation layers of the DEMs, the elevation and slope raster images with the smallest cell sizes possible were obtained, as shown in Fig. 2b, c. Because the minimum cell size that could be considered with 1:5000 DEMs was $5 \mathrm{~m}$, the raster with cell sizes of $5 \mathrm{~m}$ by $5 \mathrm{~m}$ was processed. Based on the elevation raster, the flow direction datasets were computed. The Flow Direction tool creates a raster of flow direction from each cell to its steepest downslope neighbor (Olivera et al. 2002a). From the flow direction raster, the flow accumulation datasets were obtained (Fig. 2d). The Flow Accumulation tool creates a raster of accumulated flow into each cell. With a flow accumulation grid as the accumulated weight of all cells flowing into each downslope cell, valleys can be defined through the use of the flow accumulation value (Olivera et al. 2002b) (Fig. 2e). For a more accurate visualization of valley areas, the properties of the flow accumulation grids were altered in various ways. Through trial and error and by comparing with the actual site survey (or the valley layer of the digital map) and the flow accumulation grids, the accumulation grids (white lines in Fig. 2e) having 0.1 STD of valley shape (geometry of valley based on the DEMs) were applied to define the boundary of valleys.

After setting a pour point (output point) on the route of the assessed expressway, the flow direction and pour point were taken into consideration to obtain the watershed. The Watershed tool creates the drainage areas that contribute to the flow from the land surface to the water system (Esri 2002) (Fig. 2f). Through the Extract by Mask tool, the slopes of the cell in the watershed area were obtained (Fig. 2g). Through the histogram in the raster properties, 
(a)

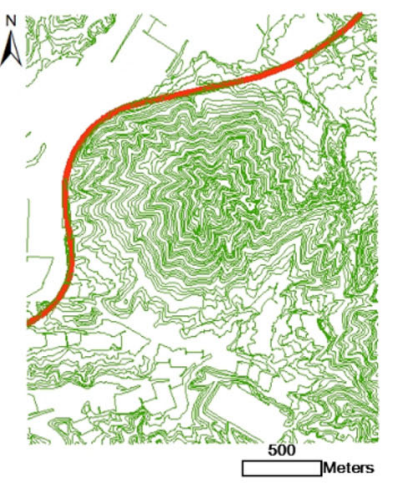

(b)

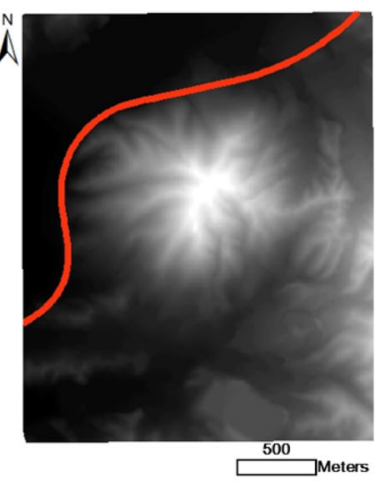

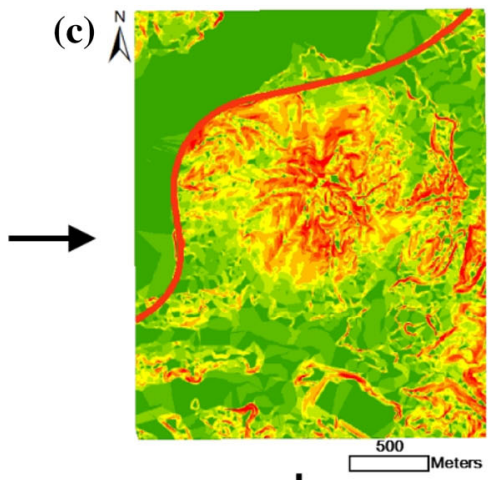

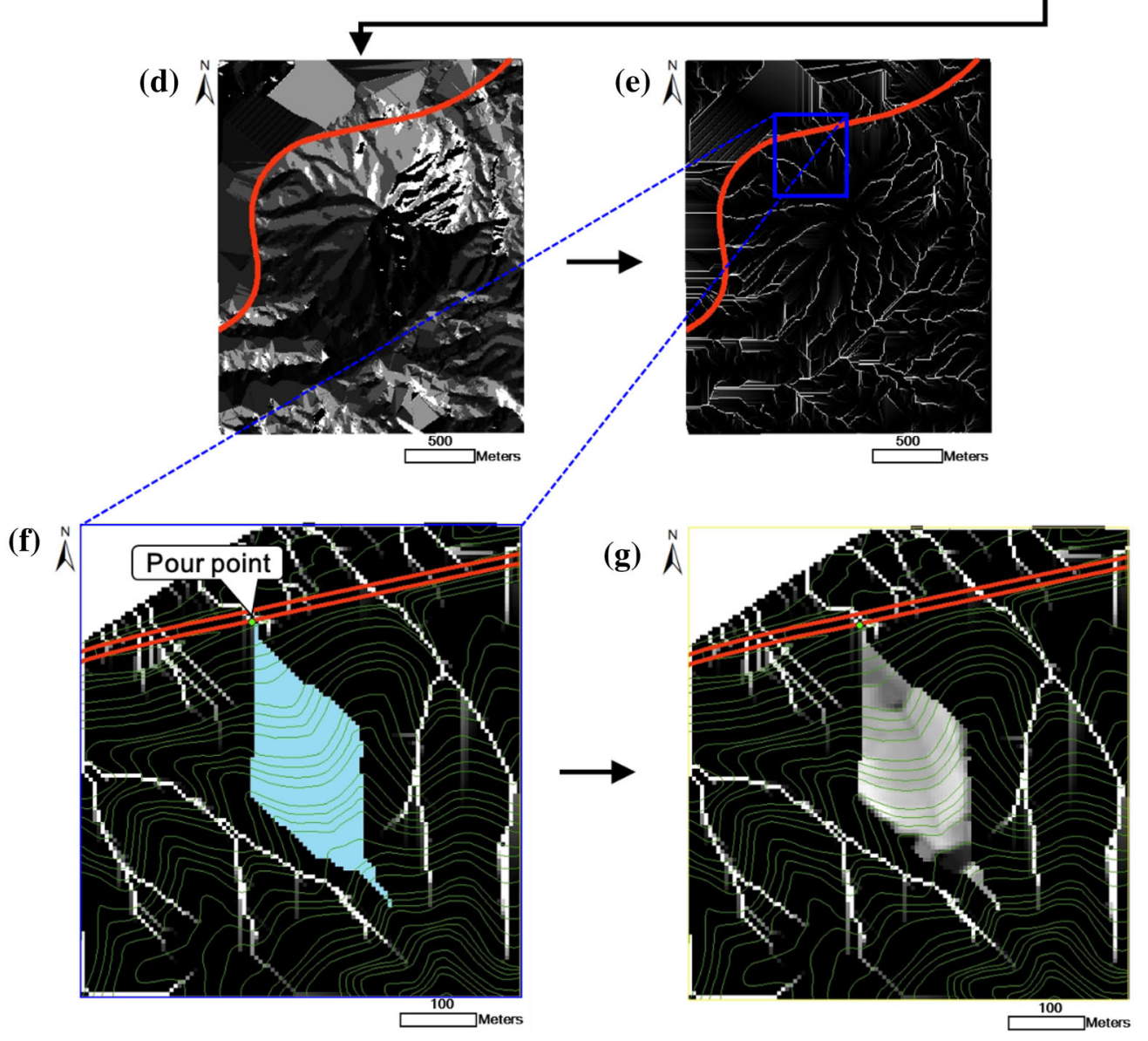

Fig. 2 Details of sequence application (using the proposed GIS-based framework) for watershed slope attributes: a polyline and point entity of DEM, b DEM for elevation, $\mathbf{c}$ DEM for slope, $\mathbf{d}$ flow direction, $\mathbf{e}$ flow accumulation, $\mathbf{f}$ watershed area, $\mathbf{g}$ DEM for watershed slope

the values for the attributes of the mean watershed slope and area percentage of the watershed with slopes over $35^{\circ}$ were acquired. Because the slope raster can indicate the steepest slope with regard to the surrounding pixels and the flow direction, but not the slope in the valley direction, the previously obtained slope raster cannot be used to derive the attributes related to the whole valley. Other means should be used for the acquisition of the valley slope data. An approach that assesses the slope through the elevation raster in the valley direction was proposed and applied.
From the flow accumulation layer, the valley shapes in the watershed were obtained. The valley paths were manually plotted on the elevation layer. The elevations of the cells in the path of the valley were obtained through the Extract by Mask tool of ArcGIS using the plotted valley path and elevation layer. With the length of the plotted valley path, and the total elevation difference between the expressway and the highest point in the valley path, the mean valley slope was simply calculated as follows: 
Mean valley slope $\left(\Phi_{i}\right)=\tan ^{-1}\left(\frac{\Delta H}{L_{\text {path }}}\right)$

$\Delta H$ is the elevation difference between the expressway and the highest point in valley path, while $L_{\text {path }}$ is the length of the plotted valley.

In the estimation and prediction stage, the valley in which a debris flow will initiate is unknown. Therefore, for watersheds with more than one valley, all valleys in the watershed were considered in the process. The mean valley slopes for each valley were calculated, and were averaged using the valley lengths as weight factors:

Overall mean valley slope $=\frac{\sum_{i=1}^{n}\left(\phi_{i} \cdot L_{i}\right)}{\sum_{i=1}^{n} L_{i}}$

$\Phi_{i}$ is the mean valley slope of the individual valley and $L_{i}$ is the length of the individual valley separated by the watershed DEMs.

The extracted DEMs obtained through the Extract by Mask tool did not properly represent the valley directions, showing abrupt valley direction changes at right angles (Fig. 3a). In order to appropriately assess the slopes in the actual flow directions of the valleys for the calculation of the length percentage of the valley with slopes over $15^{\circ}$, additional ArcGIS tools were used. The extracted valley path elevations of cells were converted to points through the Raster to Point tool, and were assigned to the map coordinate system (Fig. 3b). With the Buffer tool, a buffer of $5 \mathrm{~m}$ was set around the manually plotted valley path (Fig. 3c). In order to obtain the valley path points that are positioned inside the $5 \mathrm{~m}$ buffer zones of the plotted valley path, the Intersect tool was used. Through the process, only the valley path points that were in the vicinity of the actual valley path were obtained (Fig. 3d). Using the shape value (as file type of ArcGIS) of extracted points, the slope between the DEMs in the direction of the valley travel path was calculated using Microsoft Excel. Through the calculation results of the type of shape files, the distances between cells with slopes of over $15^{\circ}$ were obtained, which in turn allowed the calculation of the length percentage of a
Fig. 3 Details of sequence application (using the proposed GIS-based framework) for valley slope attributes: a elevation extracted for cells on valley path, b cell elevation converted to points, $\mathbf{c}$ buffer applied on valley path, d intersect of buffer and cell points (a)
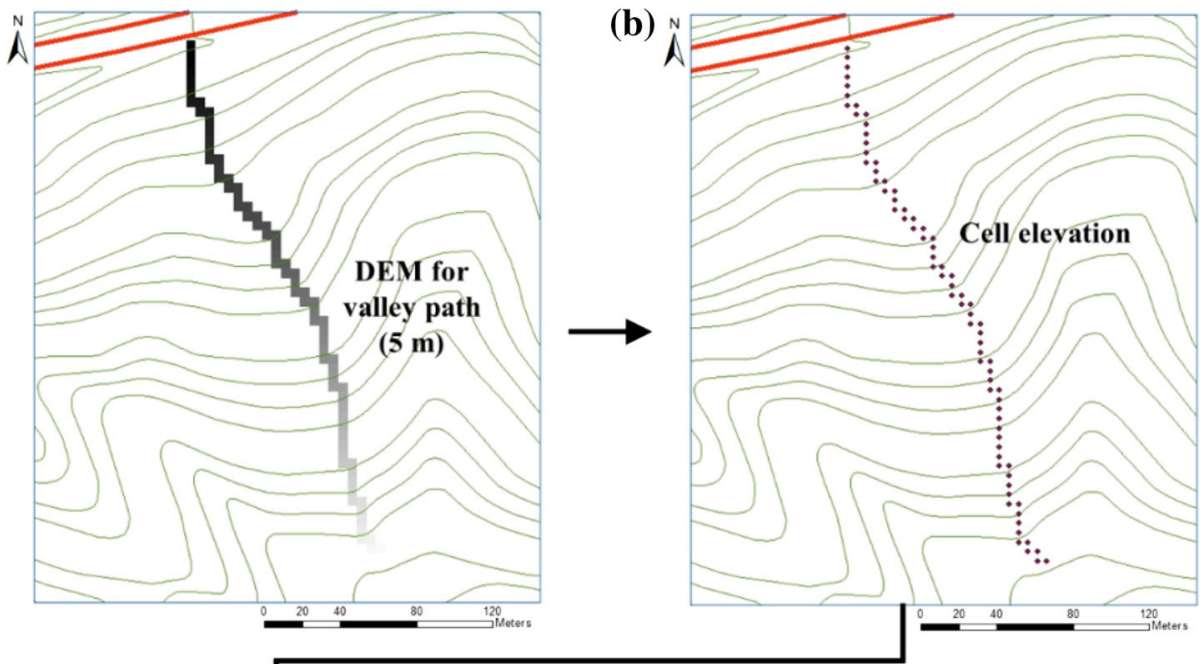

(c)

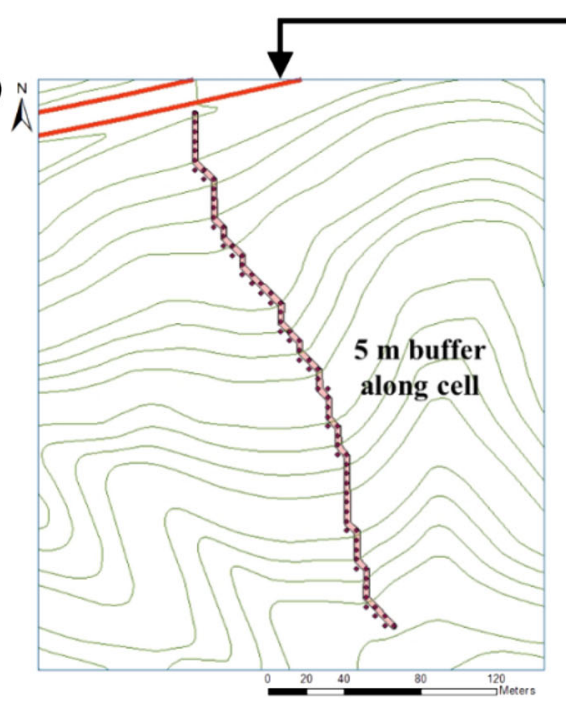

(d)

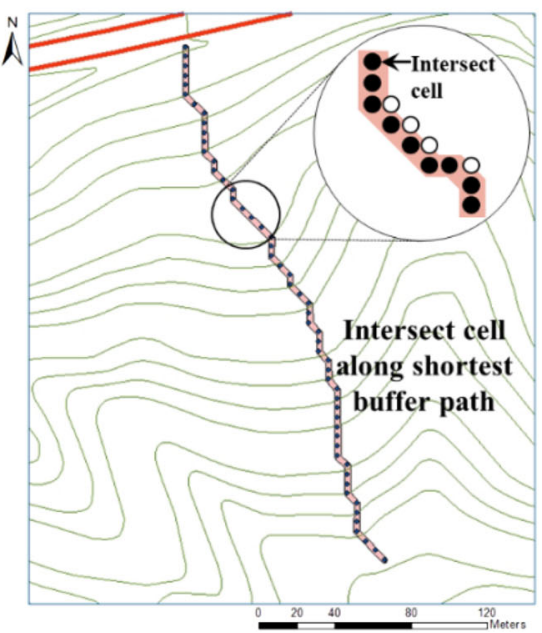


valley with slopes over $15^{\circ}$. According to the mean valley slope calculation process in watersheds with more than one valley, the length percentage of valley with slopes over $15^{\circ}$ was calculated using a similar process:

Overall length percentage of valley with slopes over $15^{\circ}$

$$
=\frac{\sum_{i=1}^{n}\left\{\left(L_{15}\right)_{i}\right\}}{\sum_{i=1}^{n} L_{i}}
$$

$\left(L_{15}\right)_{i}$ is the length of valley with slopes over $15^{\circ}$ for the individual valley.

\subsection{Attribute Processing for the Vulnerability Value}

From the expressway design files (Korea Expressway Corporation 2009), the volume of area available for sedimentation was calculated by simplifying the area as a triangular pyramid bounded by the valley and expressway embankment (Fig. 4). The volume of the margin area of sedimentation is calculated using Eq. 4. The drainage facility information of each watershed was obtained through the expressway design files, and the attribute points were determined according to the grading standard set by the KEC (Table 2).

Sedimentation volume $\left(\mathrm{m}^{3}\right)=\frac{1}{6}(L \times H \times W)$

\subsection{Quantification of Rainfall Criteria for Hazard Class}

According to the KEC method, the rainfall recurrence periods (ranging from 2 years to more than 500 years) were used as trigger values of the landslide hazard. But to immediately determine the rainfall event by linking the
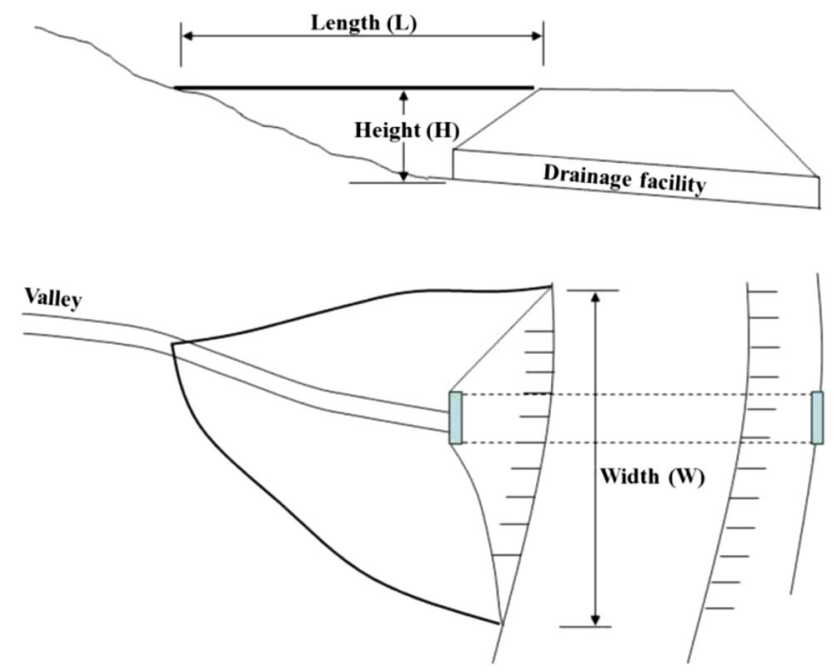

Fig. 4 Schematic of sedimentation volume for debris flow. Source Korea Expressway Corporation (2009). Reprint with permission of the Korea Expressway Corporation network sever of meteorological observatories and realtime estimates of the landslide hazard, it is impossible to directly apply the rainfall recurrence periods for the proposed framework. Thus, rainfall recurrence periods were quantified as representative accumulated rainfall criteria: $1 \mathrm{~h}$ rainfall (Yune et al. 2010), $6 \mathrm{~h}$ rainfall (Oh and Park 2013; Ham and Hwang 2014), and 3 day rainfall (Yoo et al. 2012). The baseline rainfalls were set at the lower bounds of $1,6 \mathrm{~h}$, and 3 day rainfall data from AWS and at the major interchanges at 18 stations on the nine expressway sections in which the 163 debris-flow events (the highest number of debris-flow events from 2000 to 2009) occurred in Korea. Also, various sets of these rainfall baselines using accumulated rainfall data recorded from AWS were cross-validated with the actual damage state for early warning. These referred to the recurrence intervals of rainfall corresponding to the hazard class in the KEC-based debris-flow assessment (Choi et al. 2015). From the correlations between recurrence period and accumulated rainfall data regarding to the hazard class, the range and lower bound of $1,6 \mathrm{~h}$, and 3 day accumulated rainfall datasets were determined (Table 3). Thus, the rainfall criteria were set with the lower bound values of accumulated rainfall ranges for five hazard classes based on conservative hazard management.

The severity levels of debris flow were defined as three levels: safe, caution, and warning (Fig. 1). If the measured rainfall datasets do not correspond to all three cases of accumulated rainfall datasets, the target expressway section is considered as safe from debris-flow hazard. If more than one indicator exceeds the three baseline rainfalls with regard to the five hazard classes, the debris-flow hazard needs to be forecast as a level of caution or warning. The criteria are appropriate for conservative risk management because of the cross validation between rainfall datasets and hazard class in the case of actual damage status on the representative nine expressway sections (see Sect. 5.2). The quantified rainfall criteria for the hazard class of debris flow create difficulties for real-time management of debrisflow hazard on the national expressway, although it is desirable to apply the probability of the possible rainfall recurrence period (Choi et al. 2015). Therefore, simulations using relationships between recurrence period and accumulated rainfall data at locations where debris flows have occurred is required to establish the appropriate rainfall criteria for debris-flow risk assessment.

\section{Safety Management System for Debris-Flow Hazard}

The GIS-based safety management system for debris-flow hazard consists of a database (DB) and four systematic modules (Fig. 5). The database contains all field data and 
Table 3 Quantified rainfall criteria for hazard class based on 163 debris-flow events with accumulated rainfall records

\begin{tabular}{|c|c|c|c|c|c|c|c|}
\hline \multirow{2}{*}{$\begin{array}{l}\text { Hazard } \\
\text { class }\end{array}$} & \multirow{2}{*}{$\begin{array}{l}\text { Rainfall recurrence } \\
\text { period (year) }\end{array}$} & \multicolumn{2}{|c|}{1 hours rainfall $(\mathrm{mm})$} & \multicolumn{2}{|c|}{6 hours rainfall $(\mathrm{mm})$} & \multicolumn{2}{|c|}{3 days rainfall $(\mathrm{mm})$} \\
\hline & & $\begin{array}{l}\text { Accumulated } \\
\text { rainfall range }\end{array}$ & $\begin{array}{l}\text { Rainfall } \\
\text { criteria }\end{array}$ & $\begin{array}{l}\text { Accumulated } \\
\text { rainfall range }\end{array}$ & $\begin{array}{l}\text { Rainfall } \\
\text { criteria }\end{array}$ & $\begin{array}{l}\text { Accumulated } \\
\text { rainfall range }\end{array}$ & $\begin{array}{l}\text { Rainfall } \\
\text { criteria }\end{array}$ \\
\hline S & $2-5$ & $34.5-47.7$ & 35 & $88.6-122.8$ & 90 & $218.7-317.7$ & 220 \\
\hline A & $5-20$ & $47.7-62.2$ & 45 & $122.8-167.2$ & 125 & $317.7-443.7$ & 320 \\
\hline B & $20-50$ & $62.2-71.4$ & 60 & $167.2-195.1$ & 160 & $443.7-527.4$ & 420 \\
\hline $\mathrm{C}$ & $50-100$ & $71.4-78.3$ & 75 & $195.1-216.3$ & 195 & $527.4-586.8$ & 520 \\
\hline D & Higher than 500 & Higher than 94.2 & 95 & Higher than 265.0 & 270 & Higher than 724.5 & 720 \\
\hline
\end{tabular}

Fig. 5 Integrated framework with debris-flow hazard assessment procedures

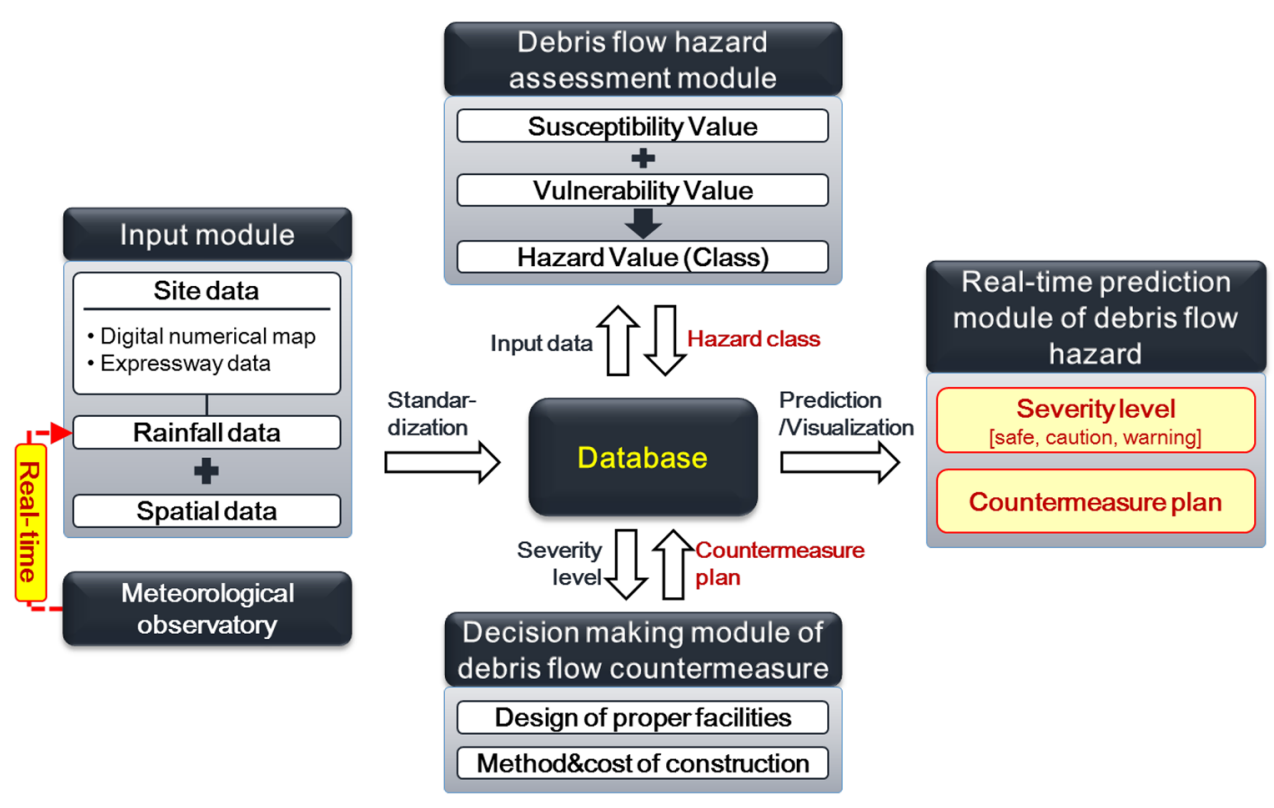

alphanumeric values according to standard data formats, which represent the outcome of data classification and standardization with spatial information. The data stored in the database can be easily utilized in the framework. The digital numerical map can be used as the basic topographical information of the system because it offers an easy way to construct topographical information for a target area. The expressway information is composed of organization categories for managing Korean expressway route data, and spatial datasets designed for various coordinates systems (longitude and latitude, GRS80, Google coordinates). The data format of rainfall events (belonging to the AWS network) was arranged previously for an expressway in Korea. The general information about rainfall observatory and time-series rainfall monitoring information were standardized considering real-time connection with AWS network. Furthermore, the results of hazard analysis and alert information were built into the database at the same time as the framework of debris-flow assessment. 
Fig. 6 Key data classes and relations of the database for the developed system

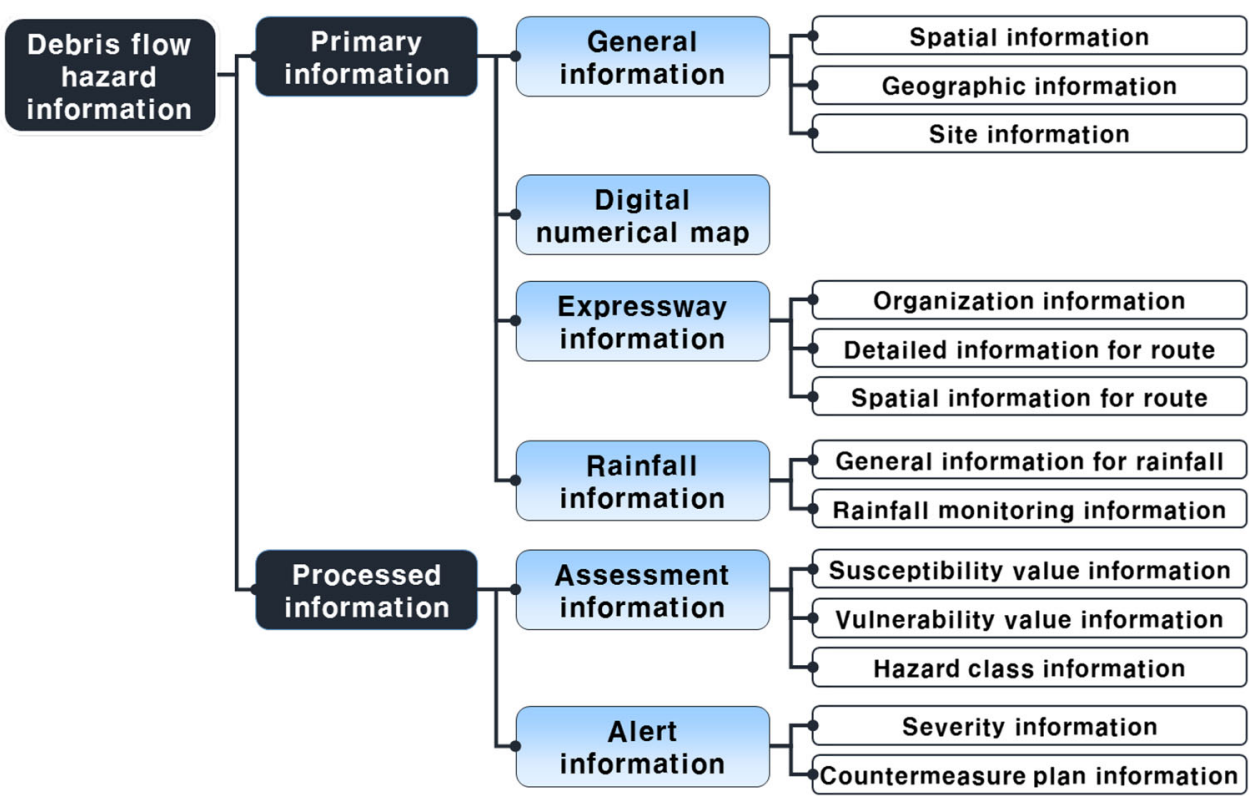

\subsection{Submodules for Rainfall and Safety Management}

Input function provides an effective way to store and arrange all collected data, including electric or nonelectric documents, general information, digital numerical maps, expressway data, rainfall monitoring data, and analyzed data, according to a standardized data format in the DB. Before applying the rainfall criteria for severity levels of debris flows, the target expressway sections are grouped within the spatial range of influence of AWS observatory ( $5 \mathrm{~km}$ radius), around the nearest AWS in Korea (Fig. 7). The influencing areas vary in different localities of a watershed, but we group the nearest expressway sections in accordance with the average distance $(5 \mathrm{~km})$. In order to link the site-specific rainfall datasets with expressway sections, additional investigation about influencing areas of AWS observatories considering the hydrological characteristics of mountain areas is important, but this study did not consider this complexity. The reclassified AWS datasets for rainfall criteria $(1,6 \mathrm{~h}$, and 3 day accumulated rainfall) are linked to the grouped expressway sections using the system database.

Using the real-time-based rainfall transmission module, as the rainfall accumulation records are transmitted from the AWS in real time, the rainfall event protocol is retained to consider the event trigger time and transferred event file. In Fig. 7, as soon as a rainfall event is detected, the rainfall

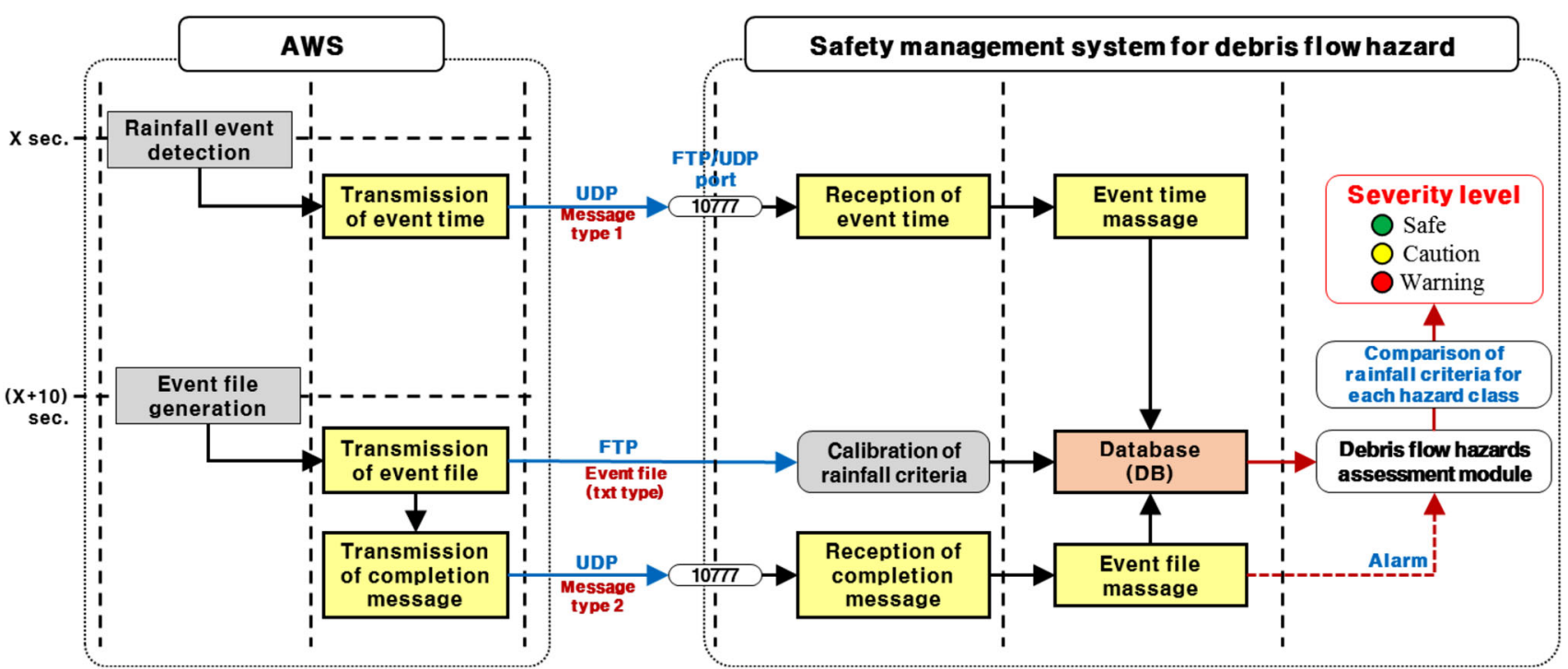

Fig. 7 Schematic flow of transmission protocol of rainfall datasets from AWS to safety management system for debris-flow hazard 
event time is transmitted from the AWS to the developed system. Then, the generated event file (stored in a oracle server) is transferred in company with the completion message, which is the computational message to inform the transmission or reception of event file and enable the DB, to operate the safety management system. At the developed system server, an event file is calibrated based on the rainfall criteria, according to the file transfer protocol. The rainfall accumulation datasets, including completion message of event time and file, are stored in system database. The alerted rainfall datasets are compared with rainfall criteria for hazard class (Table 3), and the severity level can be determined in $30 \mathrm{~s}$ after the occurrence of the rainfall event.

The real-time debris-flow assessment framework has four functional phases within the database based on the proposed schematic sequence of the debris-flow hazard assessment module (Fig. 7). In the first phase, linked with the digital numerical map and the DEM, the watershed DEM and valley layer are extracted using the ArcGIS desktop program and input system DB. In the second phase, the susceptibility value and vulnerability value for the target route are constructed into DB and combined with geospatial information. In the third phase, reliable rainfall monitoring data for the target route is transmitted from the widely distributed AWS server on a real-time basis, the routes of the completed site investigation for debris-flow hazards are grouped into the same datasets and focused on the adjacent rainfall station in target areas. The rainfall values for debris-flow hazard assessment are automatically computed based on the monitoring criteria with reference to recurrence periods of rainfall (Korea Expressway Corporation 2009 when the rainfall monitoring data is input to the DB. Once the rainfall threshold level for debris-flow hazard is reached (from the KEC method), the severity levels (safe, caution, and warning) are determined using map symbols (blue, yellow, and red symbols, respectively, in Fig. 7) at the target route in real time. In addition, sound signals and message windows are alarmed to notify the expressway administrator of the hazard status.

A decision-making module of debris-flow countermeasures was developed by standardization of site investigation reports as part of a nation-wide expressway survey in mountainous areas of Korea. As soon as the severity levels based on the rainfall monitoring data in real time are decided, it is possible that optimum countermeasures for debris-flow minimization can be rapidly put in place for a threatened target route depending on whether a caution or warning severity level is activated. Facilities (ring net, debris barrier, and so on) for debris-flow prevention can be preposition beforehand based on the site investigation for target routes having potential of debris flow. The method and cost of construction can be studied and visualized in a report, corresponding to the anticipated severity level in near real time.

The debris-flow hazard prediction function shows all the attributive information in the database by using tables and graphics according to its characteristics, on screen or as a document. Also, all data in the DB can be exported as a chart or graph. The graphic functions simultaneously display interpolated data and field data over a designated area. All of the charts and graphs can then be printed. Especially, the debris-flow hazard can be visualized and forecast as 2D maps overlaid with satellite images. Also, the severity level of the target route can be determined using zonation criteria in real time.

In this proposed framework, the computer-based method for the real-time assessment of spatial debris-flow hazard was embedded based on a stand-alone system developed using Microsoft Visual BASIC and the Esri ArcGIS developer tool (Lee and Wong 2001; Esri 2006). The ArcGIS developer tool was mainly used for the development of the database, evaluation of the results, and spatial visualization. Several assumptions and precedent assessments are needed to estimate the possible debris-flow hazard for a target site in real time, at the point at which the debris flow occurs. Especially, the precedent procedures consist of the building of the database, DEM construction, and determination of susceptibility value and vulnerability value in order to consider the overall debris flow potential in the target area, prior to the occurrence of rainfall and debris flow. As the debris flow occurs near the target site, the possible severity level can be estimated in real-time by using the rainfall data monitored from the AWS server.

\section{Application of the Assessment Method on Selected Sites}

The developed real-time GIS-based debris-flow hazard assessment framework is applied to three debris flowdamaged expressway areas in Korea to verify its validity. The standard set of the original KEC method was subsequently revised based on the case study.

\subsection{Condition of Application}

The Pyeongchang area of the Yeongdong Expressway, the Deogyu Mountain area of the Daejeon-Jinju Expressway, and the Juksan-Geochang area of the 88 Expressway in Korea were selected for investigation of their debris-flow hazards (Fig. 8). Many debris flows occurred in the Pyeongchang area of the Yeongdong Expressway during a heavy rainfall event $(244.0 \mathrm{~mm} / \mathrm{day}, 66.0 \mathrm{~mm} / \mathrm{h})$ in the summer of 2006 (Table 4). Debris flows occurred in the 
Deogyu Mountain area of the Daejeon-Jinju Expressway in the summer of 2005. The rainfall intensity in the region at that time was $312.0 \mathrm{~mm} /$ day and $54.5 \mathrm{~mm} / \mathrm{h}$. The JuksanGeochang area faced several debris flows during a heavy rainfall event in the summer of 2006. The rainfall intensity at that time was $121.0 \mathrm{~mm} / \mathrm{day}$, and $31.5 \mathrm{~mm} / \mathrm{h}$. When comparing all target areas, the Pyeongchang and Deogyu Mountain areas had similar rainfall intensities, indicating the same rainfall recurrence periods, whereas the JuksanGeochang area had the lowest daily rainfall. For each area, a test bed area was set for the application of the assessment method. A test bed with a length of $11 \mathrm{~km}$ along the Yeongdong Expressway was chosen for the Pyeongchang area. The lengths of the test beds for the Daejeon-Jinju Expressway and 88 Expressway were 3 and $2 \mathrm{~km}$ respectively, presented as black dotted lines in Fig. 8.

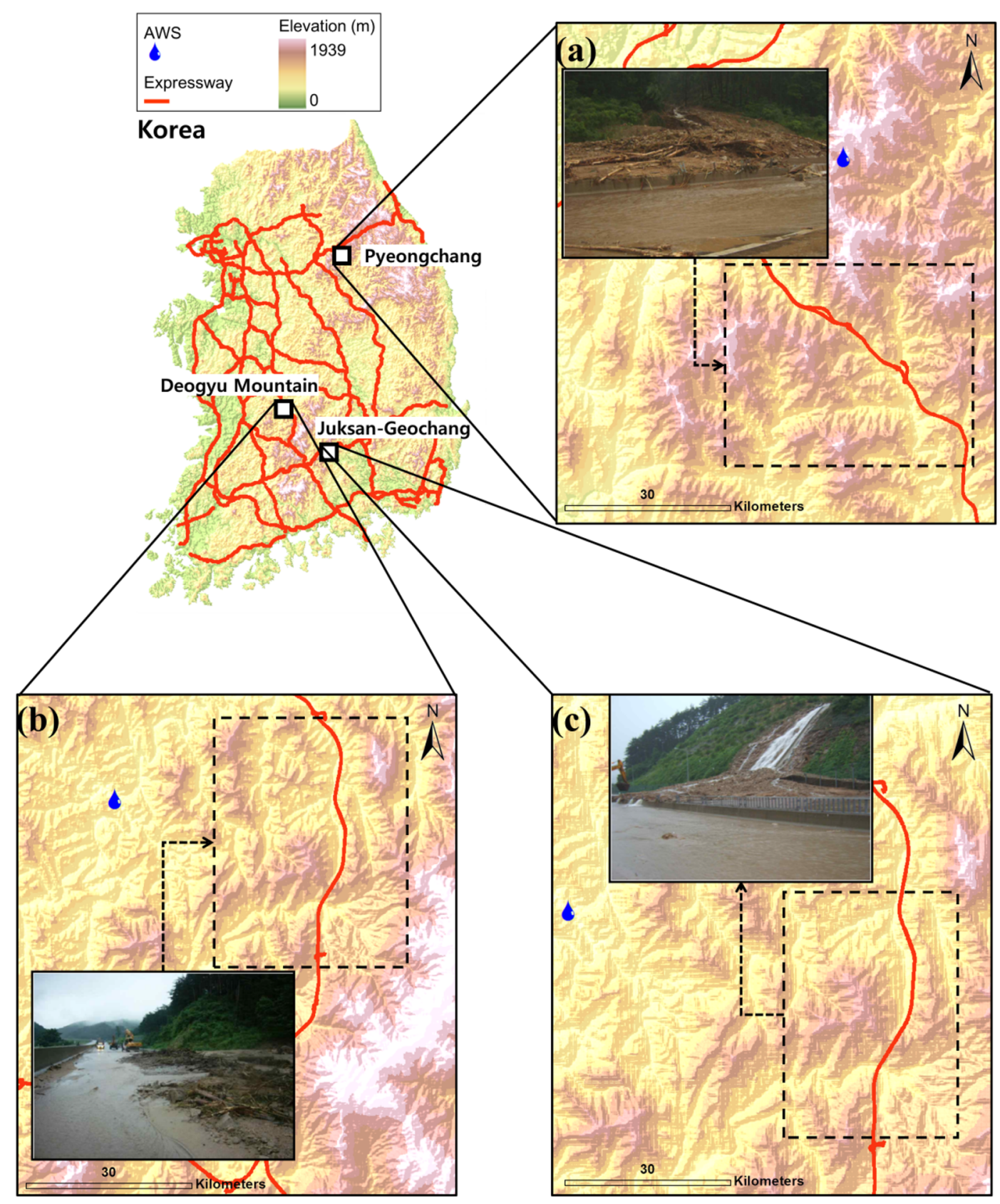

Fig. 8 Overview of assessed target regions and pictures of damaged area: a Pyeongchang area of the Yeongdong Expressway, b Deogyu Mountain area of the Daejeon-Jinju Expressway, c Juksan-Geochang

area of the 88 Expressway. Source Korea Expressway Corporation 2009). Reprint with permission of the Korea Expressway Corporation 
Table 4 State of debris-flow hazard and measured rainfall of three target expressway sections

\begin{tabular}{|c|c|c|c|c|c|}
\hline \multirow[t]{2}{*}{ Expressway section } & \multirow[t]{2}{*}{ Time of occurrence } & \multicolumn{2}{|l|}{ Rainfall (mm) } & \multicolumn{2}{|c|}{ Damage of debris flow } \\
\hline & & $\begin{array}{l}\text { Daily accumulated } \\
\text { rainfall }\end{array}$ & $\begin{array}{l}\text { Hourly max } \\
\text { rainfall }\end{array}$ & Condition & $\begin{array}{l}\text { Debris sedimentation } \\
\left(\mathrm{m}^{3}\right)\end{array}$ \\
\hline Pyeongchang area & 15 July 2006, 12:00 & 244.0 & 66.0 & Road blocked & 5000 \\
\hline $\begin{array}{l}\text { Deogyu Mountain } \\
\text { area }\end{array}$ & $\begin{array}{l}3 \text { August 2005, } \\
01: 00\end{array}$ & 312.0 & 54.5 & Road blocked & 3000 \\
\hline Juksan-Geochang area & 18 July $2006,23: 00$ & 121.0 & 31.5 & $\begin{array}{l}\text { Drainage } \\
\text { blocked }\end{array}$ & 1500 \\
\hline
\end{tabular}

\subsection{Verification of the Framework for Debris-Flow Assessment}

All existing watersheds in the selected expressway test beds were analyzed. Of all the watersheds in the selected regions, the areas with expressways positioned on bridges and tunnels, or near vast areas of fields were excluded from the analysis due to their very low likelihood of damage. Since reported debris flows were based on the damage made to road structures, those areas without any damage were not reported. No debris-flow damage was reported in areas where the space for possible sedimentation deposit is vast, and consequently these areas were not considered in the analysis process. After the exclusion of low-risk sites, watersheds were then classified according to whether or not debris-flow damage had been reported. Areas with debrisflow damages reports are referred to as "occurrences," and those without damage reports are referred to as "nonoccurrences." As a result, 18 debris-flow occurrences and 14 nonoccurrences were analyzed for the Pyeongchang area (divided into 32 subsections) based on the proposed framework for debris-flow assessment; 12 debris-flow occurrences and 8 nonoccurrences were analyzed for the Deogyu Mountain area (divided into 20 subsections); and 8 debris-flow occurrences (evaluated as 1 warning and 7 caution level according to the developed system) and 8 nonoccurrences were analyzed for the Juksan-Geochang area (divided into 16 subsections) as shown in Fig. 9. The developed safety management system for debris-flow hazard constructed the debris-flow hazard map according to hazard class for watershed and forecasted severity level linked with AWS (hourly max rainfall datasets) on realtime basis at the Jusan-Geochang area (Fig. 9).

Applications of the KEC method show results that roughly coincide with the actual debris-flow occurrences and nonoccurrences are presented in the table of hazard value (varying from 0 to 30) and hazard class (Fig. 10). Occurrence cases are roughly positioned in the upper righthand side, which indicate higher susceptibility and vulnerability values, whereas nonoccurrence cases are located

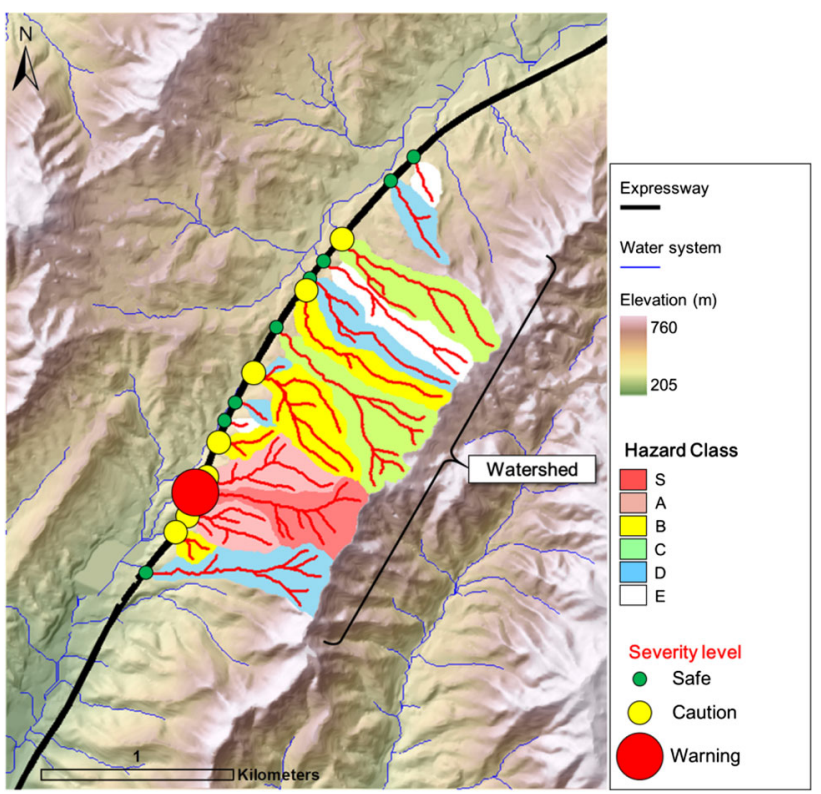

Fig. 9 Example of debris-flow hazard map based on the hazard class for watershed and severity level by simulation through real-time link with AWS in the Jusan-Geochang area at 23:03, 18 July 2006. At that time, the daily accumulated rainfall and the hourly maximum rainfall were recorded as 121.0 and $31.5 \mathrm{~mm}$, respectively

on the lower left side, with relatively lower susceptibility and vulnerability values. Although this tendency may seem correct to some extent, it does not always show flawless results. In the $\mathrm{C}$ and $\mathrm{D}$ hazard classes, both debris-flow occurrence and nonoccurrence cases are mixed up, not always indicating a result in which occurrences have higher hazard classes, and nonoccurrences fall into lower classes. Debris flows occurred even in areas with an E hazard class, which was initially expected to indicate a very low likelihood of debris flow. The total sum of susceptibility value and vulnerability value even showed a greater number of nonoccurrences than the occurrences due to the low hazard values of occurrence cases.

Although the sites showed results that generally presented higher susceptibility values and vulnerability values 


\begin{tabular}{|c|c|c|c|c|c|c|c|c|c|c|c|}
\hline 20 & E (20) & D (21) & D (22) & C (23) & B (24) & B (25) & B (26) & $A(27)$ & S (28) & S (29) & S (30) \\
\hline 19 & E (19) & D (20) & D (21) & C (22) & B (23) & B (24) & B (25) & $A(26)$ & $S$ (27) & $S(28)$ & $S(29)$ \\
\hline 18 & E (18) & D (19) & D (20) & C (21) & C (22) & B (23) & B (24) & $A(25)$ & $A(26)$ & $\Delta s_{(27)}$ & $S(28)$ \\
\hline 17 & E (17) & D (18) & D (19) & C (20) & C (21) & B (22) & B (23) & $A(24)$ & $A(25)$ & $S(26)$ & $S(27)$ \\
\hline 16 & E (16) & D (17) & D (18) & C (19) & C (20) & B (21) & B (22) & $\mathrm{OB}_{\text {(23) }}$ & $A(24)$ & $A(25)$ & $S(26)$ \\
\hline 15 & E (15) & E (16) & D (17) & D (18) & C (19) & C (20) & B (21) & B (22) & $A(23)$ & Oप口 & $A(25)$ \\
\hline 14 & E (14) & E (15) & D (16) & D (17) & C (18) & C (19) & B (20) & B (21) & B (22) & $A(23)$ & $A(24)$ \\
\hline 13 & E (13) & E (14) & D (15) & D (16) & C (17) & $\mathrm{C}(18)$ & C (19) & B (20) & B (21) & B (22) & $A(23)$ \\
\hline 12 & E (12) & E (13) & D (14) & D (15) & C (16) & $\mathcal{C}_{(17)}$ & C (18) & B (19) & $\triangle \mathrm{B} / \mathrm{p} 0)$ & В (21) & $\sqrt{A^{B(22)}}$ \\
\hline 11 & E (11) & E (12) & D (13) & D (14) & C (15) & C (16) & $\Lambda^{C(17)}$ & $\left.\triangle c \triangle^{8}\right)$ & $35(19)$ & B (20) & $\mathrm{AB}^{\mathrm{B}} \mathbf{q}^{1}$ \\
\hline 10 & E (10) & E (11) & E (12) & D (13) & $\mathrm{p}_{(14)}$ & $\square c(15)$ & C (16) & C (17) & C (18) & $\mathrm{O}_{\mathrm{B}(19) \mathrm{O}}$ & ○ (20) \\
\hline 9 & E (9) & E (10) & E (11) & D (12) & D (13) & $\mathrm{Z}^{\mathrm{c}(14)}$ & C (15) & C (16) & C (17) & $O\left(\triangle^{8}\right)$ & B (19) \\
\hline 8 & E (8) & E (9) & E (10) & D (11) & D (12) & D (13) & C (14) & xoy & C (16) & $\Delta C^{(17)}$ & $\mathrm{F}(18)$ \\
\hline 7 & E (7) & E (8) & E (9) & $\mathrm{E}(\mathbf{1 0})$ & D (11) & $\mathrm{O}_{(12)}$ & $\mathrm{O}^{\mathrm{p}(13)}$ & C (14) & $\triangle^{c}(15)$ & C (16) & C (17) \\
\hline 6 & E (6) & $E(7)$ & E (8) & $E(9)$ & D (10) & D (11) & D (12) & D (13) & C (14) & $\mathcal{C}_{(15)}$ & C (16) \\
\hline 5 & E (5) & E (6) & E (7) & E (8) & E (9) & $\mathrm{OP}_{(\mathbf{1 0})}$ & D (11) & D (12) & D (13) & D (14) & D (15) \\
\hline 4 & E (4) & E (5) & E (6) & E (7) & E (8) & E (9) & E (10) & D (11) & D (12) & $\triangle D(13)$ & $\mathrm{D}(14)$ \\
\hline 3 & E (3) & E (4) & E (5) & E (6) & $\mathrm{E}(7)$ & E (8) & E (9) & $\mathrm{E}(\mathbf{1 0})$ & E (11) & D (12) & D (13) \\
\hline 2 & E (2) & E (3) & E (4) & E (5) & E (6) & E (7) & E (8) & E (9) & E (10) & E (11) & E (12) \\
\hline 1 & E (1) & E (2) & E (3) & E (4) & E (5) & E (6) & $\mathrm{E}(7)$ & E (8) & E (9) & E (10) & E (11) \\
\hline 0 & $\mathrm{E}(0)$ & E (1) & E (2) & E (3) & E (4) & E (5) & E (6) & E (7) & E (8) & E (9) & $E(10)$ \\
\hline $\begin{array}{l}\text { Susceptibility/ } \\
\text { Vulnerability }\end{array}$ & 0 & 1 & 2 & 3 & 4 & 5 & 6 & 7 & 8 & 9 & 10 \\
\hline
\end{tabular}

\section{Pyeongchang}

\section{Occurrence :}

Deogyu Mountain

\section{Juksan-Geochang}

Nonoccurrence :

Fig. 10 Original chart of hazard class in accordance with susceptibility and vulnerability values of debris flow and occurrence and nonoccurrence cases for three expressway sections

in occurrence cases, they did not perfectly represent the total hazard value differences. But the effectiveness of the proposed framework was validated by the three cases because the potential of debris-flow hazard is generally high for the actual occurrence cases. The average of the hazard value of occurrence cases is 1.13 times that of nonoccurrence cases (Table 5). In order to appropriately represent the differences between occurrences and nonoccurrences of debris flows, modifications can be made on the grading standard of the KEC method using more validation tests based on the proposed framework, because the KEC standard set was established using logistic regression with a small number of samples of debris-flow damaged expressway sections. Specifically, grading standards for attributes need to be revised by taking into consideration the attribute values of both occurrences and nonoccurrences, maximizing the distinction between the two instances.

Table 5 Average of susceptibility value, vulnerability value, and hazard value of occurrence and nonoccurrence cases according to the original standard-based verification results

\begin{tabular}{|c|c|c|c|c|c|c|}
\hline \multirow[t]{2}{*}{ Test beds } & \multicolumn{3}{|l|}{ Occurrence case } & \multicolumn{3}{|l|}{ Nonoccurrence case } \\
\hline & Susceptibility value & Vulnerability value & Hazard value & Susceptibility value & Vulnerability value & Hazard value \\
\hline Pyeongchang & 11.67 & 8.56 & 20.22 & 9.36 & 7.64 & 17.00 \\
\hline Deogyu Mountain & 11.78 & 7.44 & 19.22 & 10.14 & 7.44 & 17.57 \\
\hline Juksan-Geochang & 11.25 & 8.33 & 19.58 & 9.63 & 8.25 & 17.88 \\
\hline Average & 11.57 & 8.11 & 19.67 & 9.71 & 7.78 & 17.48 \\
\hline
\end{tabular}


Table 6 Modified points given to attributes based on the original grading standard of KEC

\begin{tabular}{|c|c|c|c|c|}
\hline & & & Scoring Index & Points \\
\hline \multirow{24}{*}{$\begin{array}{l}\text { Susceptibility } \\
\text { Value } \\
\text { (20 points) }\end{array}$} & \multirow{12}{*}{$\begin{array}{l}\text { Initiation } \\
\text { assessment } \\
\text { (10 points) }\end{array}$} & \multirow{6}{*}{$\begin{array}{l}\text { Mean slope of } \\
\text { watershed } \\
\text { (Unit: }^{\circ} \text { ) }\end{array}$} & Higher than $30^{\circ}$ & 5 \\
\hline & & & $30^{\circ}-28^{\circ}$ & 4 \\
\hline & & & $28^{\circ}-26^{\circ}$ & 3 \\
\hline & & & $26^{\circ}-24^{\circ}$ & 2 \\
\hline & & & $24^{\circ}-22^{\circ}$ & 1 \\
\hline & & & Under $22^{\circ}$ & 0 \\
\hline & & \multirow{6}{*}{$\begin{array}{l}\text { Area } \\
\text { percentage of } \\
\text { watershed } \\
\text { with slopes } \\
\text { over } 35^{\circ} \\
\text { (Unit: \%) }\end{array}$} & Higher than $32 \%$ & 5 \\
\hline & & & $32 \%-25 \%$ & 4 \\
\hline & & & $25 \%-18 \%$ & 3 \\
\hline & & & $18 \%-11 \%$ & 2 \\
\hline & & & $11 \%-4 \%$ & 1 \\
\hline & & & Under $4 \%$ & 0 \\
\hline & \multirow{12}{*}{$\begin{array}{l}\text { Movement } \\
\text { assessment } \\
\text { (10 points) }\end{array}$} & \multirow{6}{*}{$\begin{array}{l}\text { Mean valley } \\
\text { slope } \\
\text { (Unit: }^{\circ} \text { ) }\end{array}$} & Higher than $19^{\circ}$ & 5 \\
\hline & & & $19^{\circ}-17^{\circ}$ & 4 \\
\hline & & & $17^{\circ}-15^{\circ}$ & 3 \\
\hline & & & $15^{\circ}-13^{\circ}$ & 2 \\
\hline & & & $13^{\circ}-11^{\circ}$ & 1 \\
\hline & & & Under $11^{\circ}$ & 0 \\
\hline & & \multirow{6}{*}{$\begin{array}{l}\text { Length } \\
\text { percentage of } \\
\text { valley with } \\
\text { slopes over } \\
15^{\circ} \\
\text { (Unit: \%) }\end{array}$} & Higher than $67 \%$ & 5 \\
\hline & & & $67 \%-61 \%$ & 4 \\
\hline & & & $61 \%-55 \%$ & 3 \\
\hline & & & $55 \%-49 \%$ & 2 \\
\hline & & & $49 \%-43 \%$ & 1 \\
\hline & & & Under $43 \%$ & 0 \\
\hline \multirow{12}{*}{$\begin{array}{l}\text { Vulnerability } \\
\text { Value } \\
\text { (10 points) }\end{array}$} & \multirow{6}{*}{$\begin{array}{l}\text { Debris storage } \\
\text { ( } 5 \text { points) }\end{array}$} & \multirow{6}{*}{$\begin{array}{l}\text { Volume of } \\
\text { deposit area } \\
\left(\text { Unit: } \mathrm{m}^{3}\right)\end{array}$} & No accumulation area $\left(0 \mathrm{~m}^{3}\right)$ & 5 \\
\hline & & & $0 \mathrm{~m}^{3}-100 \mathrm{~m}^{3}$ & 4 \\
\hline & & & $100 \mathrm{~m}^{3}-500 \mathrm{~m}^{3}$ & 3 \\
\hline & & & $500 \mathrm{~m}^{3}-2000 \mathrm{~m}^{3}$ & 2 \\
\hline & & & Higher than $2000 \mathrm{~m}^{3}$ & 1 \\
\hline & & & $\begin{array}{l}\text { Excessive volume of deposit area, No } \\
\text { damage guaranteed }\end{array}$ & 0 \\
\hline & \multirow{6}{*}{$\begin{array}{l}\text { Debris } \\
\text { passage } \\
\text { through } \\
\text { expressway } \\
\text { facilities } \\
\text { ( } 5 \text { points) }\end{array}$} & \multirow{6}{*}{$\begin{array}{l}\text { Size of } \\
\text { drainage } \\
\text { facility } \\
\text { (Unit: m) }\end{array}$} & Waterway & 5 \\
\hline & & & Lateral drains below D1.2 (1.31 $\left.\mathrm{m}^{2}\right)$ & 4 \\
\hline & & & Waterway box below B2.0x2.0 $\left(4 \mathrm{~m}^{2}\right)$ & 3 \\
\hline & & & Waterway box below B4.0x4.0 (16 m²) & 2 \\
\hline & & & Waterway box below B3.0xD3.0 (26 m²) & 1 \\
\hline & & & Bridges & 0 \\
\hline
\end{tabular}

Note $\mathrm{D}$ is the diameter of lateral drains and B is the width of waterway box for the scoring index of debris passage through expressway facilities. Debris passage through expressway facilities is defined as the designed sedimentation volume of debris flow from valley to waterway under the expressway

\subsection{Modifications to the Framework}

The existing KEC method assigned points to each attribute according to a grading standard set based on a few case studies of debris-flow occurrences. But it did not take the nonoccurrence cases into consideration (Kim 2012). In addition, the KEC grading standard set used all data samples collected for the study. In order to appropriately represent the differences between debris-flow occurrences and nonoccurrences, modifications can be made to the grading standard using additional tests. The three applications in this study included a large number of debris-flow occurrence sites and can be used for this purpose. 


\begin{tabular}{|c|c|c|c|c|c|c|c|c|c|c|c|}
\hline 20 & E (20) & $D(21)$ & D (22) & C (23) & B (24) & B (25) & B (26) & $A(27)$ & S (28) & S (29) & S (30) \\
\hline 19 & E (19) & D (20) & D (21) & C (22) & B (23) & B (24) & B (25) & $A(26)$ & S (27) & $S(28)$ & $5(29)$ \\
\hline 18 & E (18) & D (19) & D (20) & C (21) & C (22) & B (23) & B (24) & $A(25)$ & $A(26)$ & S (27) & $S(28)$ \\
\hline 17 & E (17) & D (18) & D (19) & $C(20)$ & C (21) & B (22) & B (23) & A (24) & $A(25)$ & $S(26)$ & $S(27)$ \\
\hline 16 & E (16) & D (17) & D (18) & $C(19)$ & C (20) & B (21) & B (22) & B (23) & $\Delta^{A(24)}$ & $A(25)$ & S (26) \\
\hline 15 & E (15) & E (16) & D (17) & D (18) & C (19) & C (20) & В (21) & B $(22$ & $A(23)$ & $A(24)$ & $A(25)$ \\
\hline 14 & E (14) & E (15) & D (16) & D (17) & C (18) & C (19) & B (20) $\Lambda$ & B (21) & C & $\mathbf{A}(23)$ & $A(24)$ \\
\hline 13 & E (13) & E (14) & D (15) & D (16) & Oc (17) & C (18) & C (19) & B (20) & $\mathrm{AB}^{(21)}$ & B (22) & $\Delta A_{(23)}$ \\
\hline 12 & E (12) & E (13) & D (14) & D (15) & C (16) & C (17) & $\triangle C(18)$ & B (19) & $\triangle \triangle^{B}\left(N_{0}\right)$ & B (21) & B (22) \\
\hline 11 & E (11) & E (12) & D (13) & D (14) & C (15) & C (16) & C (17) & C (18) & B (19) & $\triangle B(20) \triangle$ & $A_{B}(21)$ \\
\hline 10 & E (10) & E (11) & E (12) & D (13) & D (14) & $\Delta C(15) \Delta$ & C (16) & C (17) & $\mathcal{C}_{(\mathbf{1 8})}$ & $\mathrm{O}_{\text {(19) }}$ & B $(20)$ \\
\hline 9 & E (9) & E (10) & E (11) & D (12) & D (13) & $\square=(14 \square$ & C (15) & $\mathrm{C}(16)$ & C (17) & C (18) & $\mathrm{O}^{\mathbf{B}(19}$ \\
\hline 8 & E (8) & E (9) & E (10) & D (11) & $\square(12)$ & D (13) & C (14) & C (15) & $\mathrm{C}(16)$ & $\triangle c(17)$ & C (18) \\
\hline 7 & E (7) & E (8) & E (9) & E (10) & D (11) & D (12) & D (13) & $\mathrm{Oc}_{(14)} \backslash$ & C (15) & C (16) & C (17) \\
\hline 6 & E (6) & E (7) & E (8) & E (9) & D (10) & D (11) & D (12) & D (13) & $\mathrm{C}_{(\mathbf{1 4})}$ & $\mathcal{C}_{(15)}$ & C (16) \\
\hline 5 & E (5) & E (6) & E (7) & E (8) & OE (9) & D (10) & $\mathrm{OD}(11)$ & D (12) & D (13) & $\beth^{\mathrm{p}}(14) \triangle$ & $\square(15 \bigcirc$ \\
\hline 4 & E (4) & E (5) & E (6) & $E(7)$ & E (8) & E (9) & E (10) & D (11) & $\mathrm{O}_{(12)}$ & D (13) & D (14) \\
\hline 3 & E (3) & E (4) & E (5) & $E(6)$ & E (7) & E (8) & OE (9) & $\triangle E(10)$ & E (11) & D (12) & D (13) \\
\hline 2 & E (2) & E (3) & E (4) & E (5) & E (6) & E (7) & E (8) & E (9) & $\triangle E(10)$ & E (11) & E (12) \\
\hline 1 & E (1) & E (2) & E (3) & E (4) & OE (5) & E (6) & E (7) & E (8) & E (9) & E (10) & $\mathrm{E}(11)$ \\
\hline 0 & $\mathrm{E}(0)$ & E (1) & E (2) & E (3) & E (4) & E (5) & E (6) & E (7) & E (8) & E (9) & E (10) \\
\hline $\begin{array}{l}\text { Susceptibility/ } \\
\text { Vulnerability }\end{array}$ & 0 & 1 & 2 & 3 & 4 & 5 & 6 & 7 & 8 & 9 & 10 \\
\hline
\end{tabular}

\section{Pyeongchang Deogyu Mountain Juksan-Geochang}

\section{Occurrence :}

Nonoccurrence :

Fig. 11 Modified chart of hazard class in accordance with susceptibility and vulnerability values of debris flow applying the modified scoring criteria and occurrence and nonoccurrence cases for three expressway sections

Table 7 Average of susceptibility value, vulnerability value, and hazard value of occurrence and nonoccurrence cases according to the modified standard-based verification results

\begin{tabular}{|c|c|c|c|c|c|c|}
\hline \multirow[t]{2}{*}{ Test beds } & \multicolumn{3}{|l|}{ Occurrence case } & \multicolumn{3}{|l|}{ Nonoccurrence case } \\
\hline & Susceptibility value & Vulnerability value & Hazard value & Susceptibility value & Vulnerability value & Hazard value \\
\hline Pyeongchang & 13.53 & 9.50 & 23.03 & 8.52 & 5.62 & 17.00 \\
\hline Deogyu Mountain & 14.62 & 8.52 & 23.14 & 9.01 & 6.92 & 17.57 \\
\hline Juksan-Geochang & 15.31 & 9.02 & 24.33 & 7.12 & 7.55 & 17.88 \\
\hline Average & 14.47 & 9.01 & 23.50 & 8.22 & 6.70 & 14.91 \\
\hline
\end{tabular}

To modify the grading standards, the average values of attributes in the three target areas were calculated. When calculating these average values, the mismatched cases (between estimated severity level and actual damage) were eliminated from the calculation. Likewise, occurrence cases that showed considerably high hazard values, such as 25 and higher, and nonoccurrence cases with total values of
11 and lower, were considered as outliers for statistical normalization and were not considered when calculating the average values. After calculating the average values of each attribute for the occurrence and nonoccurrence cases of the three target areas, the highest attribute values of the occurrence and nonoccurrence cases were respectively defined as the upper and lower boundaries of each scoring 
index. The range of each scoring index of the four susceptibility value attributes was divided into six classes using equal intervals. Logistic regression was performed to reestablish the grades of scoring indices in the range of $0-5$. Results of logistic regression analysis for the four susceptibility value attributes indicate that the six grades have weights of $0.29,0.24,0.19,0.14,0.10$, and 0.05 , respectively. Accordingly, the redefined grades of the scoring indices were assigned points from 0 to 5 . The modified susceptibility grading standard is presented in Table 6. The vulnerability grading standard was also modified based on the debris-flow occurrence and nonoccurrence cases of the three target areas (Table 6).

Although the grading standard of the original KEC method was established based on 30 field applications (KEC 2009), the scale of damage by debris flow during the considered period was very small (Kim 2014). Considering the fact that only a very small number of the considered sites had deposit areas with volumes exceeding $2000 \mathrm{~m}^{3}$, the grading standard was modified to reflect this range, that is, the highest class of debris storage was altered from above $5000 \mathrm{~m}^{3}$ to above $2000 \mathrm{~m}^{3}$. The other standards were also modified accordingly.

Based on the same condition of application for the three target areas, the hazard value and hazard class were determined using the revised grading standard. On the scoring chart, the occurrence cases are distributed in hazard classes $\mathrm{S}, \mathrm{A}$, and $\mathrm{B}$, which have a high potential of debris flow, as shown in Fig. 11. In contrast, the points of nonoccurrence cases are distributed in hazard class $\mathrm{C}, \mathrm{D}$, and $\mathrm{E}$, which have comparatively lower potential for debris flow. In addition, the average of the hazard value of occurrence cases is 1.58 times that of nonoccurrence cases (Table 7); this is significantly higher than the result (1.13) using the original KEC standard. Moreover, the method has potential to be improved with more data accumulation and more case histories. Also attributes other than those regarding slope should be considered, such as watershed size and valley curvature. According to Kim (2014), with larger watershed sizes both the debris-flow initiation risk and occurrence risk increase. With larger valley bending ratios, more debrisflow materials are subjected to sedimentation, lowering the possibility of damage on road structures.

\section{Conclusions}

In this study, to provide preliminary information for rapid decision making of evacuations or restoration measures, and to prevent secondary disasters caused by debris flows, a GIS-based real-time framework of debris-flow hazard assessment for expressway sections was proposed based on the KEC debris-flow hazard assessment method. First, the KEC-based method was standardized using Esri ArcGIS, which enabled various attribute datasets to be acquired in an objective and quantitative manner with a fixed data acquisition sequence. Second, considering the real-time link with the AWS network, the rainfall recurrence periods were quantified as accumulated rainfall using trigger values of actual debris-flow events. Based on the optimized KEC debris-flow hazard assessment method, a safety management system for debris-flow hazards was developed based on the GIS platform. For field applicability evaluation, the framework was applied on three expressway sections in Korea: the Pyeongchang area of the Yeongdong Expressway, the Deogyu Mountain area of the Daejeon-Jinju Expressway, and the Juksan-Geochang area of the 88 Expressway. The reliability of the assessment method was investigated by comparing with actual debris-flow occurrence and nonoccurrence cases. A revised grading standard set was proposed and validated in a case study of damaged expressways in comparison with the KEC method. In the future, additional attributes including watershed size and bending of valley should be considered in the hazard assessment.

Acknowledgments This research was supported by the Basic Research Project of the Korea Institute of Geoscience and Mineral Resources (KIGAM) and the National Research Foundation of Korea (NRF) Grant (No. 2015R1A5A7037372) funded by the Korean Government (MSIP). The authors sincerely acknowledge the support and guidance provided by the editors and reviewers. We especially thank the Korea Expressway Corporation for its leadership and support.

Open Access This article is distributed under the terms of the Creative Commons Attribution 4.0 International License (http://crea tivecommons.org/licenses/by/4.0/), which permits unrestricted use, distribution, and reproduction in any medium, provided you give appropriate credit to the original author(s) and the source, provide a link to the Creative Commons license, and indicate if changes were made.

\section{References}

Ayalew, L., H. Yamagishi, and N. Ugawa. 2004. Landslide susceptibility mapping using GIS-based weighted linear combination, the case in Tsugawa area of Agano River, Niigata Prefecture, Japan. Landslides 1(1): 73-81.

Ayalew, L., and H. Yamagishi. 2005. The application of GIS-based logistic regression for landslide susceptibility mapping in the Kakuda-Yahiko Mountains, Central Japan. Geomorphology 65(1): 15-31.

Blahut, J., P. Horton, S. Sterlacchini, and M. Jaboyedoff. 2010. Debris flow hazard modelling on medium scale: Valtellina di Tirano, Italy. Natural Hazards and Earth System Sciences 10(11): 2379-2390.

Carrara, A., F. Guzzetti, M. Cardinali, and P. Reichenbach. 1999. Use of GIS technology in the prediction and monitoring of landslide hazard. Natural Hazards 20: 117-135.

Choi, J.S., J.W. Jeong, O.G. Kwon, C.K. Chung, and S.D. Lee. 2015. Simulation of debris-flow early warning using real time rainfall 
monitoring. Proceedings of 2015 KGS Spring National Conference, 19-20 March 2015, Seoul, Korea, 25-29.

Dai, F.C., and C.F. Lee. 2002. Landslide characteristics and slope instability modeling using GIS, Lantau Island, Hong Kong. Geomorphology 42(3): 213-228.

Esri. 2002. Arc Hydro. California: Esri Press.

Esri. 2006. ArcGIS 9: Using ArcGIS Desktop. California: Esri Press.

Feusto, G., C. Alberto, C. Mauro, and R. Paola. 1999. Landslide hazard evaluation: A review of current techniques and their application in a multi-scale study, Central Italy. Geomorphology 31: $181-216$

Ham, D.H., and S.H. Hwang. 2014. Review of landslide forecast standard suitability by analysing landslide-inducing rainfall. Journal of Korean Society of Hazard Mitigation 14(3): 299-310.

Hungr, O., S.G. Evans, M.J. Bovis, and J.N. Hutchinson. 2001. A review of the classification of landslides of the flow type. Environmental \& Engineering Geoscience 7(3): 221-238.

Iverson, R.M. 2000. Landslide triggering by rain infiltration. Water Resources Research 36(7): 1897-1910.

Jakob, M., and O. Hungr. 2005. Debris-flow hazards and related phenomena. New York: Springer.

Keller, E.A., and D.E. DeVecchio. 2008. Natural hazards: Earth's processes as hazards, disasters, and catastrophes, 2nd edn. Upper Saddle River, NJ: Prentice Hall.

Kim, K.S. 2012. Analysis of rainfall characteristics inducing shallow failure of road cut slope. Ph.D. Dissertation, Seoul National University, Seoul.

Kim, S.R., H.S. Kim, G.S. Kim, and C.K. Chung. 2014. Debris-flow risk assessment along expressways in Korea using GIS. Proceedings of Geohazards 2014, 20-21 November 2014, Kathmandu, Nepal, 159-164.

Korea Expressway Corporation (KEC). Expressway and Transportation Research Institute. 2009. Development of debris flow hazard analysis method and its application. Expressway and Transportation Research Institute Research Report.

Kritikos, T., and T. Davies. 2015. Assessment of rainfall-generated shallow landslide/debris-flow susceptibility and runout using a GIS-based approach: Application to western Southern Alps of New Zealand. Landslides 12(6): 1051-1075.

Lee, J., and D.W.S. Wong. 2001. Statistical analysis with ArcView GIS. Toronto, ON: Wiley.
Lee, S., and B. Pradhan. 2007. Landslide hazard mapping at Selangor, Malaysia using frequency ratio and logistic regression models. Landslides 4: 33-41.

Lee, S.W., G.H. Kim, C.Y. Yune, H.J. Ryu, and S.J. Hong. 2012. Development of landslide-risk prediction model through database construction. Journal of Korea Geotechnical Society 28(4): 23-33.

Lin, P.S., J.Y. Lin, J.C. Hung, and M.D. Yang. 2002. Assessing debris flow hazard in a watershed in Taiwan. Engineering Geology 66: 295-313.

Oh, J.R., and H.J. Park. 2013. Establishment of landslide rainfall threshold for risk assessment in Gangwon area. Journal of Korean Society of Hazard Mitigation 13(3): 43-51.

Ohlmacher, G.C., and J.C. Davis. 2003. Using multiple logistic regression and GIS technology to predict landslide hazard in northeast Kansas, USA. Engineering Geology 69(3-4): 331-343.

Olivera, F., J. Furnans, D. Maidment, D. Djokic, and Z. Ye. 2002. Drainage systems, ArcHydro: GIS for water resource. Redlands, CA: ESRI Press.

Olivera, F., D. Maidment, and D. Honeycutt. 2002. Hydro networks, ArcHydro: GIS for water resource. Redlands, CA: ESRI Press.

Park, D.W., N.V. Nikhil, and S.R. Lee. 2013. Landslide and debris flow susceptibility zonation using TRIGRS for the 2011 Seoul landslide event. Natural Hazards and Earth System Sciences 13: 2833-2849.

Paulín, G.L., M. Bursik, J.L. Hubp, L.M.P. Mejía, and F.A. Quesada. 2014. A GIS method for landslide inventory and susceptibility mapping in the Río El Estado watershed, Pico de Orizaba volcano, México. Natural hazards 71(1): 229-241.

Wang, C., S. Li, and T. Esaki. 2008. GIS-based two-dimensional numerical simulation of rainfall-induced debris flow. Natural Hazards and Earth System Sciences 8: 47-58.

Yoo, N.J., D.H. Yoon, J.K. Um, D.G. Kim, and B.S. Park. 2012. Analysis of rainfall characteristics and landslides at the west side area of Gangwon Province. Journal of the Korean GeoEnvironmental Society 13(9): 75-82.

Yune, C.Y., K.J. Jun, K.S. Kim, G.H. Kim, and S.W. Lee. 2010. Analysis of slope hazard-triggering rainfall characteristics in Gangwon Province by database construction. Journal of the Korean Geo-Environmental Society 26(10): 27-38. 